\title{
MOBILE MARKETPLACE AS A MEDIUM FOR SELLING MICRO SMALL MEDIUM ENTERPRISE PRODUCTS
}

\author{
Iwan Firdaus, Yanto Ramli, Harefan Arief, and Margono Setiawan \\ Universitas Mercu Buana Jakarta, Indonesia \\ Universitas Brawijaya, Indonesia.
}

\begin{abstract}
The development of technology has not only changed the way people communicate, but also their trading methods. Where many e-commerce sites have begun to appear which are useful for becoming a place for buying and selling goods online that can be used by entrepreneurs. This opportunity was not missed by the SMEs, where this marketplace can be utilized by the creative industries. The reason is that the obstacle always faced is marketing. Now with e-commerce like a fresh breeze for them because by using the marketplace their market will likely be wider and promotions are much cheaper. E-commerce or marketplace for SMEs is actually the same as a mall or shopping place which distinguishes it online. Like a shopping center, selling on e-commerce services also requires promotion in cyberspace. Seeing how much activity is spent using the marketplace as meeting daily needs, this is what makes this marketplace hunted. Not only by users but also entrepreneurs . Enthusiastic community increased because it was supported by adequate infrastructure and easy access. The Investment Coordinating Board (BKPM) revealed the value of investment in the digital market sector in 2017 reached USD 5 billion. This makes the marketplace the most sought after economic sector (Outletz.ID, 2018).
\end{abstract}

Keyword: Digital Market, E-Commerce, Entrepreneurs, Marketplace

\section{INTRODUCTION}

The development of technology has not only changed the way people communicate, but also their trading methods. Where many e-commerce sites have begun to appear which are useful for becoming a place for buying and selling goods online that can be used by entrepreneurs. This opportunity was not missed by the SMEs, where this marketplace can be utilized by the creative industries. The reason is that the obstacle always faced is marketing. Now with e-commerce like a fresh breeze for them because by using the marketplace their market will likely be wider and promotions are much cheaper. E-commerce or marketplace for SMEs is actually the same as a mall or shopping place which distinguishes it online. Like a shopping center, selling on e-commerce services also requires promotion in cyberspace. Seeing how much activity is spent using the marketplace as meeting daily needs, this is what makes this marketplace hunted. Not only by users but also entrepreneurs . Enthusiastic community increased because it was supported by adequate infrastructure and easy access. The Investment Coordinating Board (BKPM) revealed the value of investment in the digital market sector in 2017 reached USD 5 billion. This makes the marketplace the most sought after economic sector (Outletz.ID, 2018).

Marketplace has a concept like a mall that seems to be on the internet. Marketplace owners have the role of parties who bring buyers and sellers together on their websites. Some e-commerce sites like Blibli and Blanja are examples of sites that curate their sellers. There is also a free opportunity for everyone to become a seller, such as Elevenia, Tokopedia, and Bukalapak. Models like this are called marketplaces. By carrying out the concept of the marketplace, e-commerce can develop quickly.

But concepts like this can backfire if you're not careful. Seeing the benefits and broad benefits, of course the use of the marketplace will be of much benefit and help the growth of small businesses that have potential products and are needed by the market.

The changing shopping behavior of the Indonesian population from 2011 until now has made the marketplace growth in the country grow rapidly. Consumers tend to like shopping online because it tends to be more practical, modern, can be done all the time without having to make it difficult to do mobility out of the house when you need the desired item. Of course this is a good opportunity for most small businesses to take an active 
role in offering their merchandise using the marketplace in Indonesia. Of course, this condition provides considerable opportunities and profits for businesses who want to peddle their goods in a marketplace that already has a good reputation in Indonesia.

According to the presentation of Handayani (2017) discusses the role of e-commerce that supports the development of online trading activities through purchasing decisions made by customers, on another occasion Majid (2017) the application of e-commerce in Indonesia is seen from the perspective of consumers' perceptions and trust in carrying out transactions secaca online in several leading marketplaces in Indonesia. While Harlipan (2017) peeling through comparative research on the interface between a two forces marketplace Indo $\mathrm{n}$ e it is bukalapak and Tokopedia in supporting online shopping activities.

\section{THEORETICAL FRAMEWORK}

Over the past decade, there has been a proliferation of online markets, ranging from eBay and Amazon to Uber and Airbnb. This online market does not exist without trust. Buyers need to trust that the seller accurately $m$ enggambarkan products or services and meet the transaction as promised. The seller must believe that the buyer will pay, and in the case of service and rental, will comply with the agreed terms of service. Trust between buyers and sellers is made possible by a reputation system and design choices made by the online market .

Marketplace applies the B2B (Business to Business) business model, this can be seen from the marketplace itself, which is also a business entity that serves a business entity or vendor who wants to market its products. In addition, the marketplace also applies the $\mathrm{B} 2 \mathrm{C}$ (Business to Customers) business model which is used when vendor members of the marketplace serve their customers. Whereas e-commerce applies only the B2C (Business to Business ) business model without involving other business entities

Marketplace is an E-Business model that deals with sellers and buyers. Market Place in Indonesia is one of the national economic driving forces in the context of facing the era of globalization. For this, MarketPlace needs to be developed in an orderly, reasonable and efficient manner.

Marketplace is an internet-based online media (web-based) place for conducting business activities and transactions between buyers and sellers. Buyers can find as many suppliers as possible with the desired criteria, so that they get according to market prices. Whereas suppliers / sellers can find out companies that need their products / services.

M ccording Nathasya (2018), the marketplace can dedinisikan as a website or online application that facilitates the buying and selling process from a variety of stores. Marketplace has a concept that is more or less the same as traditional markets. Basically, marketplace owners are not responsible for goods sold because their job is to provide a place for sellers who want to sell and help them to meet customers and make transactions more simply and easily. The transaction itself is regulated by the marketplacenya.

According to Pahlevi (2017) in his presentation, Marketplace is an application or website that provides online trading facilities from various sources. Owner of the website or application does not have any product and their business presents only the product of other users and then facilitate it. Marketplace is a business model where the website does not only help to promote products but also bridges online transactions between sellers and buyers. In recent years the Marketplace has been booming in Indonesia because the Marketplace makes it easy for consumers to shop online. Marketplace provides a variety of product choices so consumers will be able to choose the items that they want. Surely this is very beneficial for businesses because they don't need to bother bringing visitors to their site

\section{METHOD}

The method used is practice by using an android phone that can directly be installed in the Tokopedia and Bukalapak marketplaces. The material to use the marketplace as a marketing medium for MSME products is wider and promotion is much cheaper. The training aims to explain in more detail the application of the marketplace and foster insight, knowledge and awareness about the nature of the importance of the marketplace in assisting the marketing of MSME products. UMKM participants are directly taught. The method used in the implementation of this service is the presentation (lecture), the assignment practice and question and answer. The Community Service Activities target the participants of the PKK neighborhood in the South Kembangan sub-district who already have business units and also individual communities who have small-scale businesses in the South Kembangan sub-district area. Community Services held 
on $28 \mathrm{M}$ arch 2019 is implemented in the form of sales training using a mobile marketplace for mothers of PKK members Village Kembangan South South and Youth Kembangan, West Jakarta.

\section{RESULTS AND DISCUSSION}

Introduction to Marketplace and E-commerce. The e-commerce utilization training session begins with introducing participants to Market Place and e-commerce. e-commerce is a term used to refer to a trading activity through an electronic system such as the internet. At present Indonesia has become the largest market share in Southeast Asia for e-Commerce players. With a population of more than 269 million people and the high use of smartphones today and is projected to continue to increase. There are already many sites that are classified as Market Place. Names - names like Lazada, Tokopedia, elevenia, bukalapak, Blibli, JD.id, Shopee and many series of names, has been the perpetrators of online trading services provider. In 2018, Tokopedia became the third most visited e-Commerce platform in Southeast Asia even though it was only available in one country, with an average of 125 million visitors. Previously, the State of Internet report from Akamai stated that Indonesia was the country with the highest growth in digital adoption in the world, beating India and China. This is a great opportunity for market leaders in Indonesia to also have a strategic position in the e-Commerce industry on a regional scale.

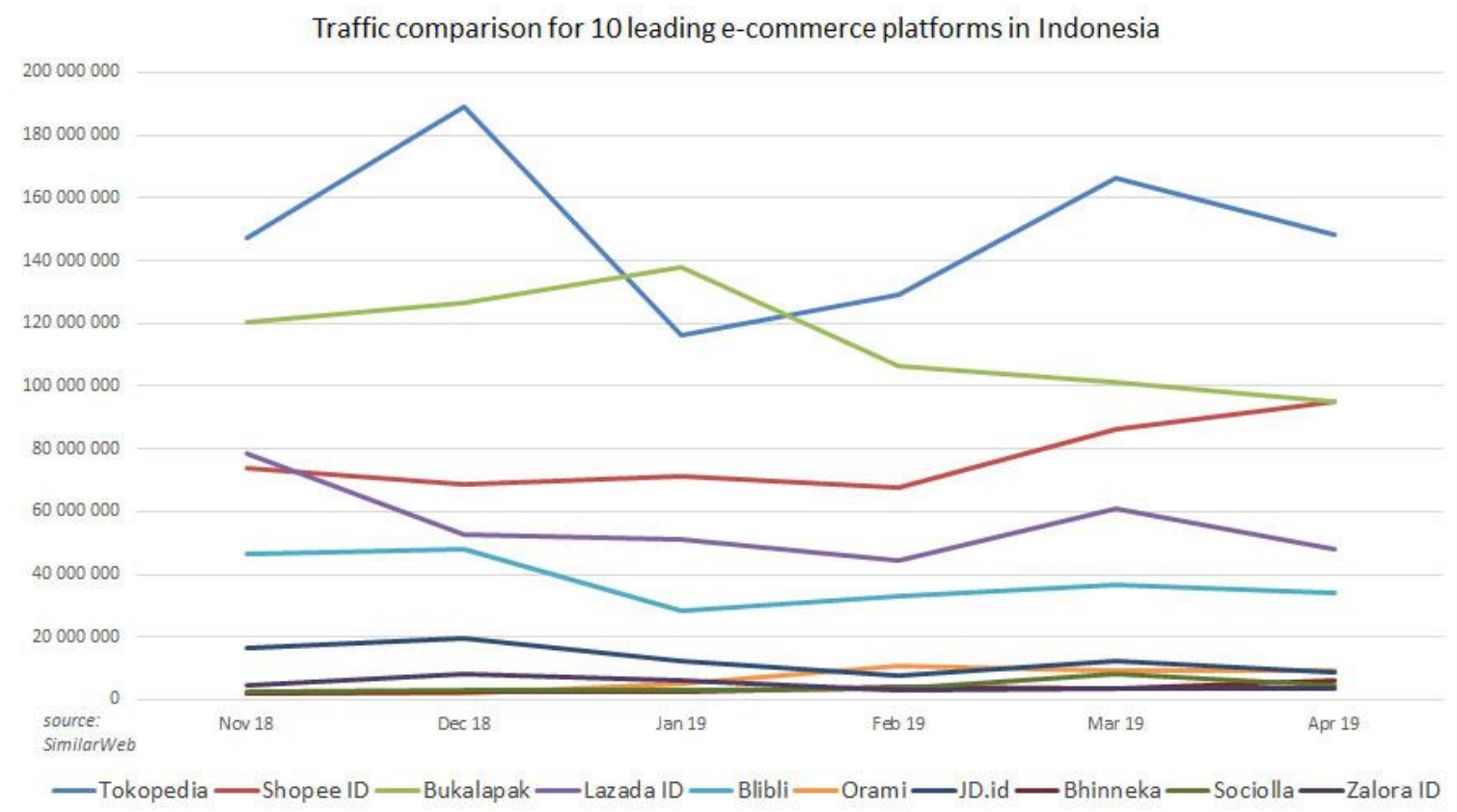

Source: https://aseanup.com/top-e-commerce-sites-indonesia/

( accessed 12 August 2019)

Systematics of service activities Stories about how to apply, activity photos, material discussed, questions that arise or problems experienced by participants in using the application. Material (Introduction to Online Marketing, Shopee, Tokopedia) .

This PPM activity takes the form of a Workshop or Training on the theme of internet introduction training, email creation and insert file in the form of objects or for PKK cadres which have been carried out on March 28, 2019 from $14.00-16.30$ with the following results:

1. From discussions conducted with PKK cadre participants who run the MSME business and Adolescent South Kembangan Village, it was revealed that so far they had actually been quite familiar with computers and the internet. But they have not yet come to know that the internet is very useful in conducting promotions and marketing using marketplace platforms both through cellphones and computers

2. During the Internet training and utilization of the Tokopedia and Bukalapak marketplace, an explanation was given about the advantages of having an online store in marketing MSME products from the PKK group. 
3. After holding the Workshop or Training, participants began to be inspired by their entrepreneurial spirit and will create their own online shop for the benefit of marketing MSME products from PKK cadres as well as teenagers who have the desire to do business online.

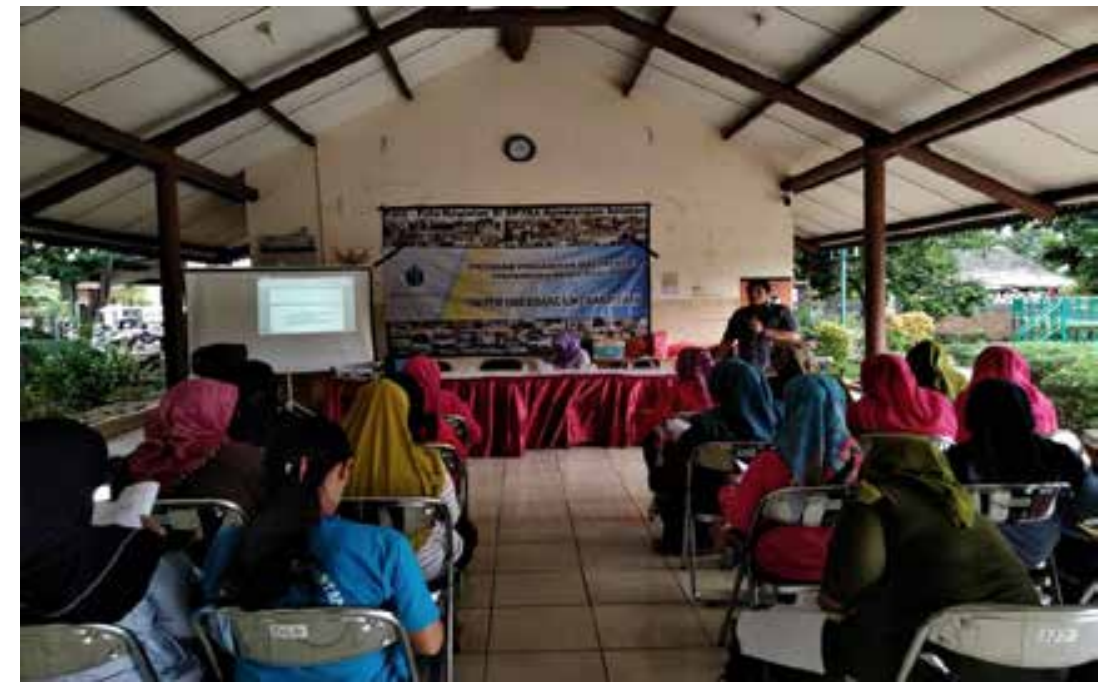

Photo session of the marketplaceUMKM training session with PKK participants from Kembangan Selatan Village, West Jakarta

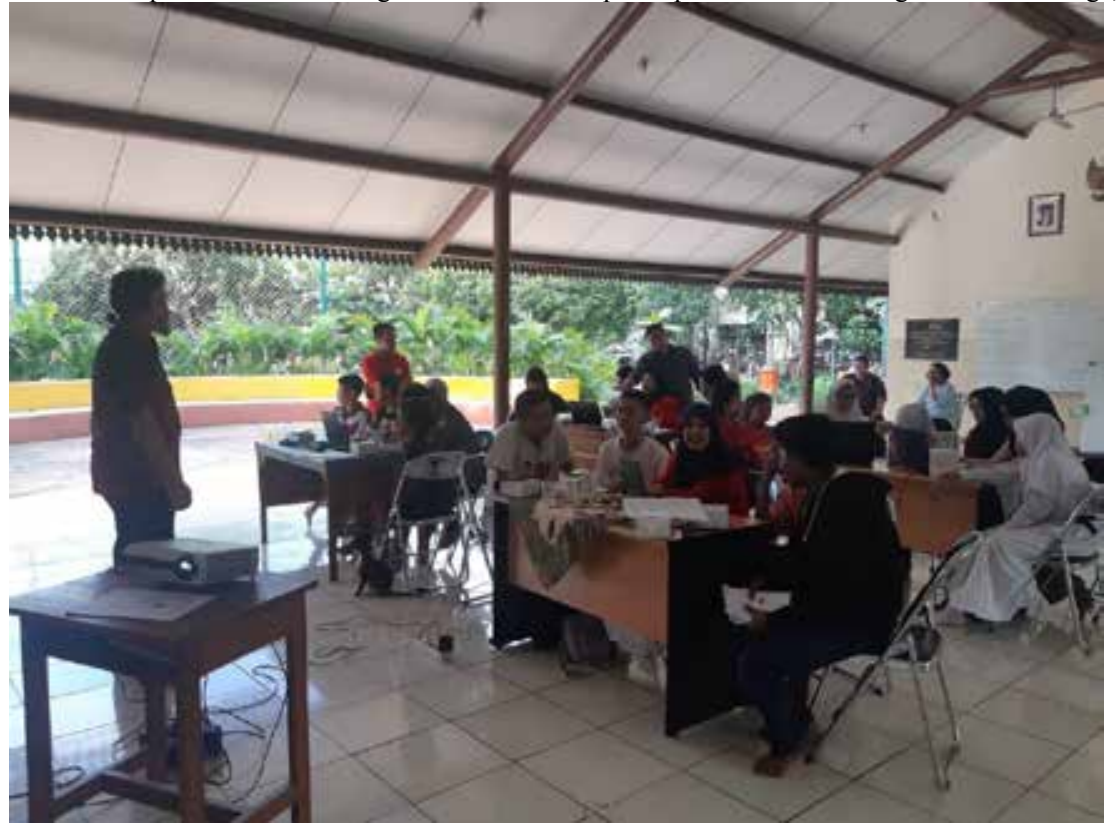

Photo session of the UMKM marketplace training session with Youth participants in Kembangan Selatan Village, West Jakarta

\section{CONCLUSION}

Through this Community Service activity, see the potential for the development of MSMEs in using e-commerce and the Marketplace for economic development which in the end will get an increase in social quality. A series of training activities carried out in the Community Service activities show that participants have an understanding of the material and the potential to develop a business. Small business actors are parties who produce and or prepare goods physically to be sold to consumers, so the important thing that should get attention when the online sales service process starts is to know the customer or customer well, character (habit) or behavior (traits) nature) because this relates to consumer activity when consumers make an order or order process online, ordered goods must be in accordance with the goods displayed, the specifications of the goods may not differ according to promises of promotion in marketing activities, in the process of sending goods must 
use the appropriate shipping service to maintain the quality of the goods intact until the goods are accepted by consumers.

\section{REFERENCES}

Apriyanto. 2016. Mengapa Situs Marketplace di Indonesia Bisa Menjadi Begitu Populer. From https://id.techinasia.com/talk/populernya-situs-marketplace-di-indonesia.

Fitriati, Rachma, 2016, Menguak Daya Saing Wirausaha Industri Kreatif, Jakarta: Gramedia. Handayani, M. 2017. Analisis Beberapa Variabel yang Mempengaruhi Keputusan Pembelian Konsumen E-Commerce. From http://eprints.ums.ac.id/49537/3/BAB\%20I.pdf

Harlipan, Alfin. 2017. Analisis Perbandingan Customer Interface Pada Bukalapak.com Dan Tokopedia.com. Thesis, Universitas Pendidikan Indonesia.

Majid, BW. 2017. Analisis Kepercayaan dan Persepsi Rantai Nilai Menurut Konsumen Pada ECommerce. From http://eprints.umm.ac.id/38115/2/jiptummpp-gdl-bimowirion-48198-2- babi.pdf. Makmur, Rakhmat, 2011. Bisnis Online. Yogyakarta: Informatika.

Nathasya. 2018. Apa Itu Marketplace. From https://www.dewaweb.com/blog/apa-itu-marketplace/. Outletz.ID., 2018. 5 Alasan Penting Anda Perlu Mencoba Jualan di Marketplace. From https://outletz.id/5-alasanpenting-anda-perlu-mencoba-jualan-di-marketplace/

Pahlevi. 2017. Pengertian Marketplace dan Jenis-jenis Marketplace. From https://www.pahlevi.net/pengertianmarketplace/.

Reza. 2018. Dorong UMKM, Kominfo Gandeng 6 Marketplace Indonesia. From https://www.liputan6.com/news/read/3488224/dorong-umkm-kominfo-gandeng-6-marketplaceindonesia.

Soelton, Mochamad, Nugrahati, Tati, 2018. How Complaining Behaviors Effect on Coping Stress and Anxiety?. International Journal of Saudi Journal of Business and Management Studies (SJBMS). Vol. 3, No. 6. 623-628.

Soelton et al, 2019. Gender : Stress Levels On Performance In Modern Industry. International Journal Archives of Business Research (United Kingdom). Vol. 7, No 2. 72-81

Soelton et al, 2018. Toward The Best Strategy In Minimizing The Spread of Drug Users. International Conference On Community Development In Asia. Vol 1. No 1. 171-176 